\title{
Microbial metabolism of chlorosalicylates: accelerated evolution by natural genetic exchange
}

\author{
Miguel Angel Rubio ${ }^{1}$, Karl-Heinrich Engesser ${ }^{2}$, and Hans-Joachim Knackmuss ${ }^{3}$ \\ 1 Technische Universität Hamburg-Harburg, Abt. für Gewässerreinigungstechnik, D-2100 Hamburg 90, Federal Republic of Germany \\ 2 Lehrstuhl für Chemische Mikrobiologie der Bergischen Universität, Gesamthochschule Wuppertal, D-5600 Wuppertal 1 , \\ Federal Republic of Germany \\ ${ }^{3}$ Institut für Mikrobiologie der Universität Stuttgart, D-7000 Stuttgart 1, Federal Republic of Germany
}

\begin{abstract}
Methylsalicylate-grown cells of Pseudomonas sp. WR401 cometabolized 3-, 4- and 5-substituted halosalicylates to the corresponding halocatechols. Further degradation was unproductive due to the presence of high levels of catechol 2,3-dioxygenase. This strain acquired the ability to utilize 3-chlorobenzoate following acquisition of genes from Pseudomonas sp. B13 which are necessary for the assimilation of chlorocatechols. This derivative (WR 4011) was unable to use 4- or 5-chlorosalicylates. Derivatives able to use these compounds were obtained by plating WR 4011 on 5-chlorosalicylate minimal medium; one such derivative was designated WR 4016. The acquisition of this property was accompanied by concomitant loss of the methylsalicylate phenotype. During growth on 4- or 5-chlorosalicylate the typical enzymes of chlorocatechol assimilation were detected in cell free extracts, whereas catechol 2,3-dioxygenase activity was not induced. Repeated subcultivation of WR 4016 in the presence of 3-chlorosalicylate produced variants (WR 4016-1) which grew on all three isomers.
\end{abstract}

Key words: Mineralization - Hybrids - Chlorocatechol assimilation - Pseudomonas sp. B13

In recent decades large amounts of halogenated aromatics have been released into the biosphere as a result of extensive industrial and agricultural applications. Although some representatives of this class of compounds with low toxicity such as chlorobenzoates or chlorophenoxyacetates are totally degraded by single organisms (Dorn et al. 1974; Evans et al. $1971 \mathrm{a}$, b; Hartmann et al. 1979) the majority of these xenobiotics are incompletely degraded in natural communities (Horvath 1972; Morris and Barnsley 1982). Others, less susceptible to biological transformations (Alexander 1975), remain unchanged for long periods of time, posing serious environmental and health hazards. In view of this problem the evolution of bacterial strains with complete catabolic sequences has received special attention for the total degradation of recalcitrant chemicals in heavily

Offprint requests to: $\mathrm{H}$.-J. Knackmuss

Abbreviations. CS, chlorosalicylate; MS, methylsalicylate; 3CB, 3-chlorobenzoate; nal ${ }^{r}$, nalidixin-resistant; $\operatorname{str}^{r}$, streptomycin-resistant; C230, catechol-2,3-dioxygenase; C120, catechol-1,2-dioxygenase; HMSH, 2-hydroxymuconic semialdehyde hydrolase or 2-hydroxy-6-oxo-hexa-2,4-dienoic acid-hydrolase; HMSD, 2-hydroxymuconic semialdehyde dehydrogenase; Dienlacton hydrolase, 4-carboxymethylenebut-2-en-4-olide hydrolase contaminated areas or in industrial sewage plants (Leisinger et al. 1981). One experimentally simple strategy for the enhanced evolution of haloaromatic degrading bacterial strains has proved to be successful (Reineke and Knackmuss 1979): naturally existing cometabolic activities which convert haloaromatics into halocatechols plus halocatechols assimilating sequences (Dorn and Knackmuss 1978a,b; Schmidt and Knackmuss 1980), previously residing in separate bacteria, were combined in hybrid organisms with novel (Latorre et al. 1984) or expanded (Reineke and Knackmuss 1980; Reineke et al. 1982 b; Schwien and Schmidt 1982) phenotypes. In this paper we report the transfer of genes coding for chlorocatechol dissimilation from Pseudomonas sp. B13 into the methylsalicylate degrading bacterium Pseudomonas sp. WR 401. Transconjugants with the capability to utilize 3-, 4- and 5-chlorosalicylate as sole source of carbon and energy are described.

\section{Materials and methods}

Organisms. Pseudomonas sp. WR 401 was enriched by W Reineke (Bergische Universität - Gesamthochschule Wuppertal) from soil samples from the Göttingen area with 3-methylsalicylate (3MS), 4-methylsalicylate (4MS) or 5-methylsalicylate (5MS) as sole source of carbon. Pseudomonas sp. B13 (DSM 426) known for its ability to degrade 3-chlorobenzoate (3CB) was obtained from the DSM (Deutsche Sammlung von Mikroorganismen, Göttingen, FRG). Pseudomonas putida mt-2 (ATCC 33015) was kindly donated by P. A. Williams (Department of Biochemistry and Soil Science, University College of North Wales, Bangor, England). The nalidixic acid resistant mutant (nal') WR 4011 and the streptomycin resistant mutant $\left(\mathrm{str}^{\mathrm{r}}\right)$ WR2 were obtained from Pseudomonas sp. WR 401 and Pseudomonas $\mathrm{sp}$. B13 respectively as described in a previous communication (Reineke et al. 1982 b).

Media and culture conditions. To assure optimal aeration the organisms were inoculated into $500,1,000$ or $3,000 \mathrm{ml}$ fluted Erlenmeyer flasks containing respectively 50,100 or $300 \mathrm{ml}$ of mineral medium described elsewhere (Dorn et al. 1974). The medium was supplemented with up to $10 \mathrm{mM}$ of the appropriate carbon source from concentrated stock solutions $(0.25 \mathrm{M})$ which had been sterilized separately. The flasks were incubated at $28^{\circ} \mathrm{C}$ on a rotatory shaker at $150 \mathrm{rpm}$. Larger cell masses were harvested from 21 fermentors (Biolafitte, Maison-Lafitte, France) containing about 1.51 mineral salts medium. Air was forced at a rate 
of 11 per min and the cultures stirred at $200 \mathrm{rpm}$ at $30^{\circ} \mathrm{C}$. Growth was monitored photometrically by measuring the turbidity at $546 \mathrm{~nm}$. Solid media were prepared by adding Ion agar No. 2 (Oxoid) $1.5 \%(\mathrm{wt} / \mathrm{vol}$ ) to the mineral medium. The concentration of the carbon source in agar plates varied between 2 and $5 \mathrm{mM}$.

Conjugation experiments. Conjugation between Pseudomonas B13 and WR 401 was carried out on agar plates (Reineke and Knackmuss 1979) or in a chemostat as described previously (Hartmann et al. 1979).

Preparation of cell extracts. Cells were harvested after centrifugation for $10 \mathrm{~min}$ at $10,000 \mathrm{rpm}$, washed in $50 \mathrm{mM}$ phosphate buffer ( $\mathrm{pH} 7.5$ ), centrifuged again and resuspended in the following buffers for disruption: phosphate-acetone buffer (Nozaki 1970) for catechol-2,3-dioxygenase (C230), 2-hydroxy-6-oxohexa-2,4-dienoate hydrolase (2-hydroxymuconic semialdehyde hydrolase, HMSH) and 2-hydroxymuconic semialdehyde dehydrogenase (HMSD); Tris-hydrochloride buffer (Dorn and Knackmuss 1978a; Schmidt et al. 1980) for catechol-1,2-dioxygenase (C120) and cis,cis-muconic acid cycloisomerase:phosphate buffer (Schmidt and Knackmuss 1980) for 4-carboxymethylenebut-2-en-4-olide hydrolase (dienelactone hydrolase). Each suspension was supplemented with $3 \mathrm{mg}$ DNAse and disrupted in a French press (Aminco, Silver Springs, MD, USA) at $80 \mathrm{MPa}$. The cell debris was removed by centrifugation at $100,000 \times g$ for $1 \mathrm{~h}$ at $4^{\circ} \mathrm{C}$ and cell extracts were used at the same day. The extracts were adjusted to contain 4-6 mg protein per ml. Protein was determined by the Bradford procedure (Bradford 1976).

Enzyme assays. Specific activities in cell extracts are expressed in micromol of substrates converted or products formed per min per gram protein at $25^{\circ} \mathrm{C}$. Enzyme activities were assayed by previously described procedures, using the following substrates: 3- or 4-methylcatechol for catechol2,3-dioxygenase (C230); Nozaki 1970); in order to detect a simultaneously induced catechol-1,2-dioxygenase (C120), catechol-2,3-dioxygenase was inactivated with aceton (Nakazawa and Yokota 1977); 2-hydroxy-6-oxohexa-2,4dienoate (2-hydroxymuconic acid semialdehyde) for 2-hydroxymuconic semialdehyde dehydrogenase (HMSD) and 2-hydroxy-6-oxohepta-2,4-dienoate for 2-hydroxymuconic semialdehyde hydrolase (HMSD); Williams and Murray 1974); 3-chlorocatechol or catechol for catechol-1,2-dioxygenase (C120; Dorn and Knackmuss 1978a); 2-chloro-cis, cis-muconic acid for muconate cycloisomerase and trans-4carboxymethylenebut-2-en-4-olide for dienelactone hydrolase activities (Schmidt and Knackmuss 1980).

Activities with whole cells. The salicylate hydroxylase, which proved to be unstable in cell extract preparations, was assayed indirectly by oxygen uptake using whole cells. The rates of oxygen uptake were measured polarographically (oxygen electrode type YSI 5350; Yellow Springs, USA). Freshly harvested cells were washed and resuspended in $50 \mathrm{mM}$ phosphate buffer $(\mathrm{pH} 7.5)$ to a protein concentration of about $1.5 \mathrm{mg}$ per $\mathrm{ml}$. The endogenous respiration was registered for $3 \mathrm{~min}$ prior to inititation of the reaction by injection small volumes $(20-80 \mu \mathrm{l})$ of assay substrates from concentrated stock solutions. The final substrate concentration in the reaction vessel was $2.5 \mathrm{mM}$. Uptake rates were determined at $30^{\circ} \mathrm{C}$ with initial time course rates and corrected for endogenous $\mathrm{O}_{2}$ utilized per minute per gram protein. At $30^{\circ} \mathrm{C}$ the oxygen concentration was taken to be $0.26 \mathrm{mM}$ (Sala-Trepat et al. 1972). The protein concentration of whole cells was determined according to Schmidt et al. 1963).

Analytical methods. The concentrations of $3 \mathrm{CB}, 5 \mathrm{MS}$ and $5 \mathrm{CS}$ in the chemostat were determined by high pressure liquid chromatography (HPLC). The apparatus and solvent systems used here were the same as described previously (Brilon et al. 1981).

Chloride ion concentration was determined with an ion selective combination electrode (model 76/17, Orion Research Inc., Cambridge, MA, USA) which had been calibrated with standard solutions of $\mathrm{KCl}(0.1$ to $10 \mathrm{mM})$ in distilled water.

Chemicals. The 2-hydroxy-5-methyl-6-oxohexa-2,4-dienoate (2-hydroxy-5-methyl-6-oxomuconic semialdehyde) and 2-hydroxy-6-oxohepta-2,4-dienoate for HMSD and HMSH assays were prepared from 4-methylcatechol and 3-methylcatechol, respectively by using a heat treated cell extract of $\mathrm{m}$-toluate-grown cells of Pseudomonas putida $\mathrm{mt}-2$ (Williams and Murray 1974). 3CS, 3 MS, 4MS and 5 MS were supplied by Bayer AG, Leverkusen FRG. 4CS and 5CS were purchased from Fluka, Buchs, Switzerland. Chatechol, 3- and 4-methylcatechol, 5-fluorosalicylate (5FS) and 5-bromosalicylate (5BS) were obtained from EGA-Chemie, Steinheim, FRG. Chemicals of analytical grade were supplied by Merck, Darmstadt, FRG. 3-Chlorocatechol was prepared as described (Schreiber et al. 1980). 2-Chloro-cis,cis-muconic acid and trans-4-carboxymethylenebut-2-en-4-olide were prepared as described (Schmidt et al. 1980). Catechols and salicylates were purified by sublimation before use.

\section{Results}

Growth on methylsalicylates. Based on standard diagnostic keys (Stanier et al. 1966) the new isolate WR 401 was identified as belonging to genus Pseudomonas. It utilizes salicylate, 3-methylsalicylate (3MS), 4-methylsalicylate (4MS) and 5-methylsalicylate (5MS) but fails to grow on the isomeric chlorosalicylates as sole carbon source. Upon growth on $3 \mathrm{MS}, 4 \mathrm{MS}$ and $5 \mathrm{MS}$ in liquid culture Pseudomonas sp. WR 401 exhibits doubling times of 7.3 , 4.1 and $3.4 \mathrm{~h}$ respectively. The rates of utilization of these substrates as determined by HPLC correlate with the increase in turbidity at $546 \mathrm{~nm}$. During growth on $4 \mathrm{MS}$ and $5 \mathrm{MS}$ a yellow colour appeared in the medium, characteristic of meta ring-fission products of 4-methylcatechol. The UVspectra $\left(\lambda_{\max }\right.$ at $\mathrm{pH} 7.5$ and $\left.\mathrm{pH} 12.0=381 \mathrm{~nm}\right)$ resemble that of authentic 2-hydroxy-5-methylmuconic semialdehyde $\left(\lambda_{\max }\right.$ of $\left.382 \mathrm{~nm}\right)$ under the same conditions. The peak disappeared upon acidification ( $\mathrm{pH} 2.0$ ). Growth on $3 \mathrm{MS}$ led to accumulation of a similar compound with $\lambda_{\max }$ at $388 \mathrm{~nm}$, exactly that of 2-hydroxy-6-oxohepta-2,4-dienoate, which is the meta ring-fission product of 3-methylcatechol. No ortho ring-fission enzymes were detected after inactivation of C230 with $\mathrm{H}_{2} \mathrm{O}_{2}$ (Nakazawa and Yokota 1977). Initially during growth on salicylate both meta and gentisic acid pathway enzymes were induced. After a few generations the degradation of salicylate proceeded almost exclusively via gentisic acid. 
Table 1. Relative rates of oxygen uptake at the expense of substituted salicylates and catechols by whole cells of Pseudomonas sp. WR 401 grown with different carbon sources

\begin{tabular}{lcc}
\hline Assay substrates & \multicolumn{2}{c}{$\begin{array}{l}\text { Relative rates of oxygen uptake } \\
\text { after growth with }\end{array}$} \\
\cline { 2 - 3 } & $\begin{array}{l}\text { 4-Methyl- } \\
\text { salicylate }\end{array}$ & $\begin{array}{l}\text { 5-Methyl- } \\
\text { salicylate }\end{array}$ \\
\hline Salicylate & $100(24)$ & $100(24)$ \\
3-Methylsalicylate & 38 & 33 \\
4-Methylsalicylate & 108 & 95 \\
5-Methylsalicylate & 81 & 78 \\
3-Chlorosalicylate & 5 & 6 \\
4-Chlorosalicylate & 13 & 13 \\
5-Chlorosalicylate & 11 & 10 \\
5-Fluorosalicylate & 8 & 7 \\
5-Bromosalicylate & 10 & 11 \\
Catechol & $100(101)$ & $100(98)$ \\
4-Methylcatechol & 53 & 55 \\
4-Chlorocatechol & 51 & 48
\end{tabular}

a The oxygen uptake rates are expressed as percentages of that for salicylate $(=100 \%)$. The specific activities, given in micromol $\mathrm{O}_{2}$ per min per gram protein, appear in parentheses. Non-induced, acetate grown cells exhibited no oxygen consumption $(\leq 0.1 \mu \mathrm{mol}$ $\mathrm{O}_{2} / \mathrm{min} \cdot \mathrm{g}$ protein) for the assayed substrates

Oxygen uptake with whole cells. In contrast to some previously investigated salicylate hydroxylases (Katagiri et al. 1965; White-Stevens and Kamin 1972) the enzyme system responsible for the conversion of substituted salicylates to the corresponding catechols in strain WR 401 proved to be unstable in cell extracts. However, freshly harvested cells grown on 4- or $5 \mathrm{MS}$ took up oxygen immediately and rapidly with salicylate, $3 \mathrm{MS}, 4 \mathrm{MS}$ or $5 \mathrm{MS}$ (Table 1 ). Lower turnover rates were measured with the halosalicylates with $3 \mathrm{CS}$ showing the lowest rate of all tested substrates. The relative $\mathrm{O}_{2}$-consumption rates remained constant regardless of which methylsalicylate had been used as a growth substrate. This indicates that with these substrates only one and the same non-specific salicylate hydroxylase had been induced. Whereas both 4- and 5-methylsalicylate were good inducers of the salicylate hydroxylase no hydroxylating activities were detected in cells incubated with chlorosalicylates (data not shown).

Enzyme activities in cell extracts. Corresponding to the yellow coloration observed during the growth experiments high levels of C230 were detected in extracts of methylsalicylate grown cells of Pseudomonas sp. WR 401 (Table 2). Interestingly, high activities of this enzyme $(1,700 \mathrm{U} / \mathrm{g}$ of protein) were already present in uninduced (acetate-grown) cells. However, the presence of $4 \mathrm{MS}$ or $5 \mathrm{MS}$ in the culture medium caused a 2.5 to 3 -fold increase of C230 levels, as shown by the specific activities with catechol as assay substrate. Moreover, the relative C230-activities with various substituted catechols were constant irrespective of the growth substrate, which indicates that one and the same non-specific C 230 is present in acetate-grown cells or in cells induced during growth with isomeric methylsalicylates. In addition to the $\mathrm{C} 230$ two other meta pathway enzymes were detected in extracts of 5MS-grown cells of strain WR 401. As demonstrated by other investigators (Bayly et al. 1977; Wigmore and Bayly 1974) the concomitant presence of HMSH and HMSD activities in cell extracts must result from coordinate induction of meta pathway enzymes in this organism. The complete degradation of the ring-fission product of 4-methylcatechol, however, requires the presence of the HMSD only and not that of the HMSH (Murray et al. 1972) which is induced gratuitously.

Construction of chlorosalicylate degrading hybrids. Chlorosalicylate degrading hybrids and intermediate strains, representing evolutionary steps between the parent strains and fully adapted organisms, were readily obtained by conventional genetic crosses in continuous culture or on solid media. For the continuous culture experiment a chemostat was inocculated with 5MS-grown cells of strain WR 401 and 3CB-grown cells of Pseudomonas sp. B13. The mixed culture was continuously fed with $10 \mathrm{mM} 5 \mathrm{MS}$ and $10 \mathrm{mM} 3 \mathrm{CB}$ to allow growth and genetic exchange between the parent strains. Once a steady state had been reached the culture was stressed with gradually increasing concentrations of $5 \mathrm{CS}(0 \rightarrow 2 \mathrm{mM})$ at $D=0.018 \mathrm{~d}^{-1}$. Shortly after exposure to $5 \mathrm{CS}$ a yellow metabolite with a peak absorbance at $379 \mathrm{~nm}$ appeared in the medium. The product proved to be identical with the meta ring-fission product of 4-chlorocatechol (data not shown) indicating that $5 \mathrm{CS}$ was cooxidized. During the first 10 days of exposure to 5CS degradation of $3 \mathrm{CB}$ was incomplete so that approximately $5 \mathrm{mM}$ of the latter substrate was detectable in the culture fluid. After this period of adaptation the $3 \mathrm{CB}$ concentration rapidly dropped below $1 \mathrm{mM}$. Simultaneously the turbidity and the chloride concentration in the culture medium increased accompanied by a substancial decrease in the concentration of the meta ring-fission product. When plated on $5 \mathrm{MS}$ and $3 \mathrm{CB}$ agar plates the majority of the cells could grow on these substrates but not on $5 \mathrm{CS}$. After 30 days of adaptation the concentration of yellow products decreased significantly and the chloride concentration as well as turbidity reached a maximum. From this point on the parameters described remained constant and hybrids were isolated which could utilize $5 \mathrm{CS}$ as sole carbon source.

In order to determine the frequencies and the direction of the genetic transfer the conjugation experiment was carried out on solid media with marked parental strains. Thus, as previously reported (Reineke et al. 1982 b), mating the nal ${ }^{r}$-mutant of Pseudomonas sp. B13 with the str $^{-}$-mutant of strain WR 401 produced, at a frequency of $\leq 10^{-6}$, primary hybrid strains with the phenotype $3 \mathrm{CB}^{+}, 3 \mathrm{MS}^{+}$, $4 \mathrm{MS}^{+}, 5 \mathrm{MS}^{+}, 3 \mathrm{CS}^{-}, 4 \mathrm{CS}^{-}$and $5 \mathrm{CS}^{-}$. In addition to the streptomycin resistance the primary hybrids, designated as WR 4011, were able to grow on nicotinic acid (Nic) a property shared with WR 401 but not with Pseudomonas sp. B13. Although genetic transfer could have occurred in both directions only primary hybrids with the genetic background of WR 401 expressed the expanded phenotype. The ability to utilize chlorosalicylates manifested by the secondary hybrids WR 4016 was developed after selective plating of WR 4011 on 5 CS. These variants appeared at a frequency of $\leq 10^{-6}$ and colonies were counted after an incubation period of 5 weeks. Their phenotypic character indicates that with the acquisition of this trait WR 4016 concomitantly lost the ability to utilize methylsalicylates as growth substrates. 
Table 2. Specific activities of characteristic catabolic enzymes in cell extracts of Pseudomonas sp. WR 401 grown with acetate, 4- and 5-methylsalicylate ${ }^{a}$

\begin{tabular}{|c|c|c|c|c|}
\hline \multirow[t]{2}{*}{ Enzyme activity } & \multirow[t]{2}{*}{ Assay substrates } & \multicolumn{3}{|c|}{ Sp. act. (U/g protein) after growth with } \\
\hline & & 4-Methylsalicylate & 5-Methylsalicylate & Acetate \\
\hline Catechol 2,3-dioxygenase & $\begin{array}{l}\text { Catechol } \\
\text { 3-Methylcatechol } \\
\text { 4-Methylcatechol }\end{array}$ & $\begin{array}{r}4400(100) \\
(73) \\
(52)\end{array}$ & $\begin{array}{r}5200(100) \\
(73) \\
(53)\end{array}$ & $\begin{aligned} & 1700(100) \\
&(70) \\
&(50)\end{aligned}$ \\
\hline $\begin{array}{l}\text { 2-Hydroxymuconic semialdehyde } \\
\text { dehydrogenase (HMSD) }\end{array}$ & $\begin{array}{l}\text { 2-Hydroxy-5-methyl- } \\
\text { muconic semialdehyde }^{c}\end{array}$ & $\mathrm{ND}^{\mathrm{b}}$ & 220 & 8 \\
\hline $\begin{array}{l}\text { 2-Hydroxymuconic semialdehyde } \\
\text { bydrolase (HMSH) }\end{array}$ & $\begin{array}{l}\text { 2-Hydroxy-6-oxohepta- } \\
\text { 2,4-dienoate }\end{array}$ & $\mathrm{ND}^{\mathrm{b}}$ & 390 & 12 \\
\hline
\end{tabular}

a Cells were harvested during exponential growth. Enzyme activities were determined as described in the text. The values in parentheses represent relative activities (catechol $=100 \%$ ). For explanations of abbreviations see Materials and methods

$\checkmark \mathrm{ND}=$ not determined

c 2-Hydroxy-5-methyl-6-oxohexa-2,4-dienoate

Utilization of chlorosalicylates. The ability of WR 4016 to utilize chlorosalicylates as sole carbon source was limited to the 4- and 5-substituted isomers. No growth was observed on $3 \mathrm{CS}$. Initially, growth with $4 \mathrm{CS}$ or $5 \mathrm{CS}$ was rather slow (doubling times: $14 \mathrm{~h}$ with $4 \mathrm{CS}$ and $16 \mathrm{~h}$ with $5 \mathrm{CS}$ ). The amount of chloride eliminated corresponded to the amounts of substrate consumed. Growth was not inhibited at substrate concentrations $\leq 5 \mathrm{mmol} / \mathrm{l}$. In order to overcome longer lag periods at higher substrate concentrations $(10 \mathrm{mM} 5 \mathrm{CS})$ a higher initial cell density $\left(\mathrm{E}_{546} \geq 0.25\right)$ was required. With $10 \mathrm{mM} 5 \mathrm{CS}$ the culture reached maximum cell density $\mathrm{E}_{546}=1$. Freshly harvested cells of WR 4016 grown on either $4 \mathrm{CS}$ or $5 \mathrm{CS}$ took up oxygen without lag with various substituted salicylates. In contrast to the salicylate hydroxylase of the parent strain WR 401 (Table 1) higher relative hydroxylation rates with halogenated salicylates were measured with the transconjugant WR 4016. Concomitantly, lower turnover rates with methylsalicylates were registered in this strain (Table 3). Previous investigations have shown that prevention of meta activities is required in order to avoid misrouting of halocatechols (Reineke et al. 1982a). Moreover, for the complete metabolism of chloroarenes the induction of chlorocatechols degrading ortho pathway enzymes is necessary. Thus, no C230-activities but high activities of enzymes involved in chlorocatechol catabolism via the ortho pathway (C120, muconate cycloisomerase and 4-carboxymethylenebut-2-en4-olide hydrolase) were detected in extracts of 4CS and 5CS grown cells of WR 4016 (Table 4). Comparatively, the relative ortho ring-fission rates with various substituted catechols were essentially the same as those described for the purified enzyme of the donor strain Pseudomonas sp. B13 (Dorn and Knackmuss 1978a, b).

In order to determine the reasons as to why WR 4016 failed to grow on $3 \mathrm{CS}$ we compared the induction pattern of acetate-grown cells in the presence of $5 \mathrm{CS}$ and $3 \mathrm{CS}$. Whereas incubation with $5 \mathrm{CS}$ resulted in the synthesis of the salicylate hydroxylase, catechol 1,2-dioxygenase and 4-carboxymethylenebut-2-en-4-olide hydrolase none of these enzymes had been induced by 3 CS (data not shown). We therefore concluded that $3 \mathrm{CS}$ is not utilized because this substrate is primarily not an inducer of the salicylate hydroxylase. However, repeated subcultivation of WR 4016
Table 3. Relative rates of oxygen uptake at the expense of salicylate, methylsubstituted and halosubstituted salicylates by whole cells of strain WR 4016 and WR 4061-1

\begin{tabular}{|c|c|c|c|c|c|}
\hline \multirow[t]{3}{*}{ Assay substrate } & \multicolumn{5}{|c|}{$\begin{array}{l}\text { Relative rates of oxygen uptake } \\
\text { (strain, growth substrate) }\end{array}$} \\
\hline & \multicolumn{2}{|l|}{ WR 4016} & \multicolumn{3}{|c|}{ WR 4016-1 } \\
\hline & $4 \mathrm{CS}$ & $5 \mathrm{CS}$ & $3 \mathrm{CS}$ & $4 \mathrm{CS}$ & $5 \mathrm{CS}$ \\
\hline Salicylate & $100(13)$ & $100(12)$ & $100(23)$ & $100(17)$ & $100(16)$ \\
\hline 3-Methylsalicylate & 42 & 44 & 27 & $\mathrm{ND}^{\mathrm{b}}$ & 38 \\
\hline 4-Methylsalicylate & 52 & 55 & 41 & 38 & 35 \\
\hline 5-Methylsalicylate & 33 & 32 & 35 & 39 & 42 \\
\hline 3-Chlorosalicylate & 13 & 13 & 12 & 12 & 11 \\
\hline 4-Chlorosalicylate & 62 & 65 & 83 & 77 & 80 \\
\hline 5-Chlorosalicvlate & 60 & 60 & 72 & 75 & 73 \\
\hline 5-Fluorosalicylate & $\mathrm{ND}^{\mathrm{b}}$ & 52 & 48 & 50 & 67 \\
\hline 5-Bromosalicylate & 43 & 57 & 55 & $\mathrm{ND}^{\mathrm{b}}$ & 48 \\
\hline
\end{tabular}

a The oxygen uptake rates are expressed as percentages of that for salicylate $(=100 \%)$. The specific activities, given in micromol $\mathrm{O}_{2}$ per min per gram protein, appear in parentheses. Non-induced, acetate grown cells exhibited no oxygen consumption $(\leq 0.1 \mu \mathrm{mol}$ $\mathrm{O}_{2} /$ min $\cdot$ protein) for the assayed substrates

$\mathrm{b} \mathrm{ND}=$ not determined

in batch culture with a mixture of $5 \mathrm{CS} / 3 \mathrm{CS}$ over a period of 3 months gave rise to derivatives such as the isolate WR 4016-1 which could utilize all three halogenated salicylates as sole carbon source. Although growth of WR 4016-1 with 3CS was very slow $\left(t_{\mathrm{d}}=19 \mathrm{~h}\right)$ the growth rates with $4 \mathrm{CS}\left(t_{\mathrm{d}}=11 \mathrm{~h}\right)$ and $5 \mathrm{CS}\left(t_{\mathrm{d}}=12 \mathrm{~h}\right)$ were improved when compared to those of strain WR 4016.

Irrespective of which isomeric chlorosalicylate was used as growth substrate the same salicylate hydroxylase and C120 activities were induced in WR 4016-1 and WR 4016: the relative turnover rates with substituted salicylates and catechols were comparable in both organisms (Tables 3 and 4).

Obviously the substrate specificity of these two oxygenases remained unaltered during selection. In contrast, the specific activities of the salicylate hydroxylase, experienced 
Table 4. Relative and specific activities of catabolic enzymes in cell extracts of transconjugants WR 4016 and WR 4016-1 under different growth conditions ${ }^{2}$

\begin{tabular}{|c|c|c|c|c|c|c|}
\hline \multirow[t]{3}{*}{ Enzyme activity } & \multirow[t]{3}{*}{ Assay substrate } & \multicolumn{5}{|c|}{ Specific activities (strain, growth substrates) } \\
\hline & & \multicolumn{2}{|l|}{ WR 4016} & \multicolumn{3}{|c|}{ WR 4016-1 } \\
\hline & & $4 \mathrm{CS}$ & $5 \mathrm{CS}$ & $3 \mathrm{CS}$ & $4 \mathrm{CS}$ & $5 \mathrm{CS}$ \\
\hline Catechol-1,2-dioxygenase & $\begin{array}{l}\text { Catechol } \\
\text { 3-Chlorocatechol }\end{array}$ & $\begin{array}{r}89(100) \\
(130)\end{array}$ & $\begin{array}{r}74(100) \\
(132)\end{array}$ & $\begin{array}{r}115(100) \\
(137)\end{array}$ & $\begin{array}{r}150(100) \\
(111)\end{array}$ & $\begin{array}{r}180(100) \\
(130)\end{array}$ \\
\hline $\begin{array}{l}\text { Cis, cis-muconic acid } \\
\text { cycloisomerase }\end{array}$ & $\begin{array}{l}\text { 2-Chloro-cis,cis- } \\
\text { muconic acid }\end{array}$ & 55 & 60 & 30 & 27 & 50 \\
\hline $\begin{array}{l}\text { 4-Carboxymethylene-but-2-en- } \\
\text { 4-olide hydrolase }\end{array}$ & $\begin{array}{l}\text { Trans-4-carboxymethy- } \\
\text { lenbut-2-en-4-olide }\end{array}$ & 400 & 900 & 700 & 650 & 1200 \\
\hline Catechol 2,3-dioxygenase & Catechol & $\leq 0.1$ & $\leq 0.1$ & $\leq 0.1$ & $\leq 0.1$ & $\leq 0.1$ \\
\hline $\begin{array}{l}\text { 2-Hydroxy-muconic } \\
\text { semialdehyde hydrolase }\end{array}$ & $\begin{array}{l}\text { 2-Hydroxy-6-oxohepta- } \\
\text { 2,4-dienote }\end{array}$ & $\mathrm{ND}^{\mathrm{b}}$ & 162 & $\mathrm{ND}^{\mathrm{b}}$ & $N^{b}$ & $N^{b}$ \\
\hline
\end{tabular}

a Cells were harvested during exponential growth. Enzyme activities are given in U/g protein and were determined as described in the text.

The values in parentheses represent relative activities ( atechol $=100 \%$ )

${ }^{\mathrm{b}} \mathrm{ND}=$ not determined

a substantial increase with respect to those measured in WR 4016. Thus growth of WR 4016-1 on 4CS or 5CS resulted in a $25 \%$ higher production of salicylate hydroxylaseactivity which, compared to WR 4016, is reflected in a corresponding reduction of the doubling times with these substrates. WR 4016-1 produced high levels of the salicylate hydroxylase when incubated with $3 \mathrm{CS}$ whereas this enzyme was non inducible by this substrate in WR 4016.

In fact, the specific activities in $3 \mathrm{CS}$ grown cells of WR 4016-1 were about $30 \%$ higher than those in 4 CS- or 5CS-grown cells of WR 4016-1. Since relative activities of the salicylate hydroxylase towards 3 CS were not improved during the selection process high expression of this enzyme is necessary in order to compensate its low relative turnover rates with $3 \mathrm{CS}$.

\section{Discussion}

For total degradation of chloroaromatics the recombination in single organisms of genes encoding chlorocatechol catabolism with genes coding for naturally occurring chlorocatechol generating enzymes has proved to be an effective model for the construction of hybrid strains harboring complete catabolic pathways (Reineke and Knackmuss 1979). Thus, the transfer of the TOL plasmid from Pseudomonas putida $\mathrm{mt}-2$ into the 3-chlorobenzoate degrader Pseudomonas sp. B13 gave rise to 4-chloro and 3,5-dichlorobenzoate utilizing hybrids (Reineke and Knackmuss 1980).

Whereas in this case Pseudomonas sp. B13 acted as the recipient of part of the TOL plasmid it has been shown that genes coding for chlorocatechol degradation (HAL-genes) are also transmissible (Reineke et al. 1982 b). Thus conjugation between Pseudomonas sp. B13 and a phenol utilizing Alcaligenes strain or an aniline degrader resulted in transconjugants which could grow an chlorophenols or chloroanilines (Schwien and Schmidt 1982; Latorre et al. 1982).

In this study we expand this model to the construction of chlorosalicylate degraders. Pseudomonas sp. WR 401 grown on methylsalicylates readily cooxidized chlorosalicylates either to 3-chlorocatechol or to the dead end metabolite 2-hydroxy-5-chloro-6-oxohexa-2,4-dienoic acid. Conjugation in continuous culture or solid media between the latter organism and Pseudomonas sp. B13 gave rise to transconjugants which could totally degrade and utilize $4 \mathrm{CS}$ and $5 \mathrm{CS}$ as sole source of carbon. A closer analysis of the processes involved in the acquisition of this property revealed that the first step is the transfer of genes coding for chlorocatechol catabolism from Pseudomonas sp. B13 into Pseudomonas sp. WR 401 thereby complementing the activity of the salicylate hydroxylase with a functional degradative pathway for halocatechols (Fig. 1). The resulting primary hybrids such as WR 4011 were able to utilize $3 \mathrm{CB}$ and methylsalicylates but could not yet grow with chlorosalicylates. A similar observation has been made during the evolution of toluate/chlorobenzoate degrading hybrids (Reineke et al. 1982). Correspondingly, the metabolism of methylsalicylates and $3 \mathrm{CB}$ is compatible in WR 4011. Whereas the former substrates are utilized via the meta pathway enzymes this metabolic route appears to be unproductive for the degradation of $3 \mathrm{CB}$ (Reineke and Knackmuss 1980). The induction of the ortho pathway enzymes required for the metabolism of $3 \mathrm{CB}$ takes place only after suicide inactivation of the $\mathrm{C} 230$ by the meta ring-fission product of 3-chlorocatechol (Bartels et al. 1984; Reineke et al. $1982 \mathrm{~b}$ ). The metabolism of $4 \mathrm{CS}$ and $5 \mathrm{CS}$, however, generates 4-chlorocatechols as the only metabolite, which is not a suicide inactivator of C 230 (Reineke et al. 1982). Thus, although strain WR 4011 harbors the necessary genetic information for total degradation of $4 \mathrm{CS}$ and $5 \mathrm{CS}$ the presence of high constitutive levels of $\mathrm{C} 230$ rapidly misroutes 4-chlorocatechol so that the ortho pathway enzymes are not induced. Incubation of WR 4011 on 5CS agar plates produced variants such as WR4016. Upon growth of this organism on $4 \mathrm{CS}$ or $5 \mathrm{CS}$ all of the enzymes necessary for the complete degradation of halosalicylates via the ortho pathway (salicylate hydroxylase, catechol 1,2-dioxygenase, cis,cis-muconic acid cycloisomerase and 4-carboxymethylenebut-2-en-4-olide hydrolase, Fig. 1) but no C230 activities had been induced. Moreover, the presence of another enzyme of the meta pathway in these extracts, 


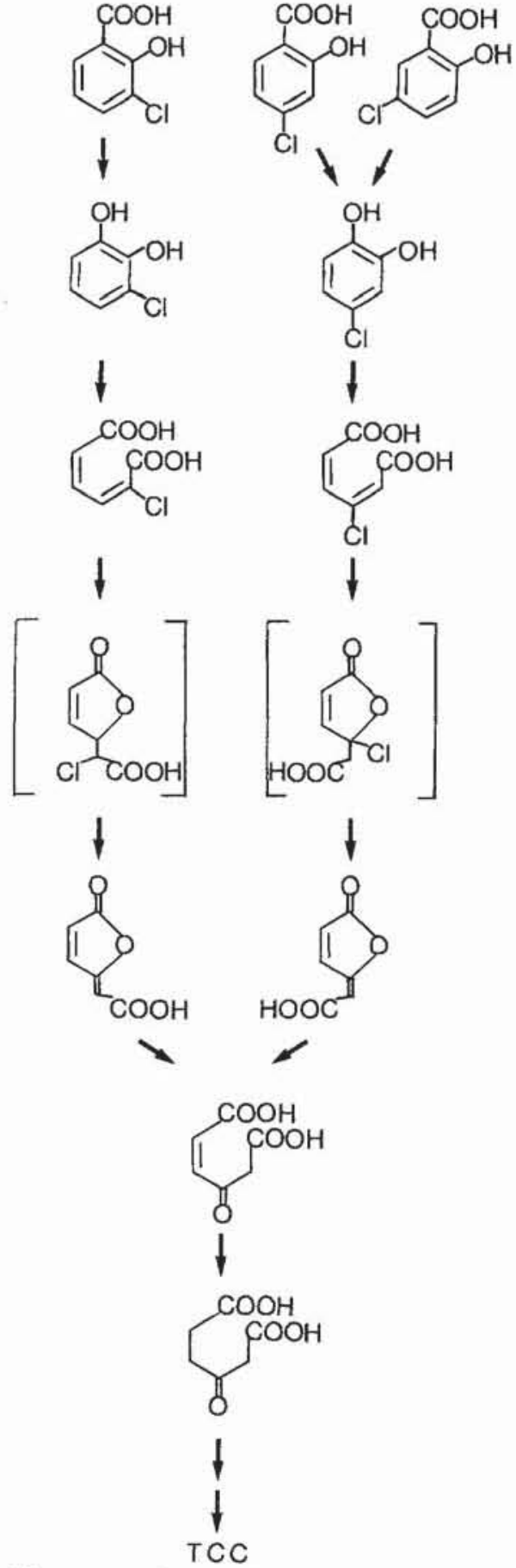

Fig. 1. Degradation of the three isomeric chlorosalicylates by in vivo or in vitro constructed Pseudomonas strains

namely the HSMH, suggests that the inactivation of the C230 must have involved a mutation in the structural gene of this enzyme (Jeenes et al. 1982). Consequently the acquisition of the $4 \mathrm{CS}^{+}, 5 \mathrm{CS}^{+}$phenotype must be accompanied by loss of the ability to utilize methylsalicylates as growth substrates. This agrees with previous reports where evidence is given that in the absence of $\mathrm{C} 230$ activities methylaromatics are converted into dead end metabolites of the ortho pathway (Knackmuss et al. 1976; Latorre et al. 1984). The fact that the relative activities of the purified catechol 1,2dioxygenase of the donor strain Pseudomonas sp. B13 (Reineke and Knackmuss 1980) were essentially the same as those of WR 4016 indicates that transfer of the HAL-genes into an 'unfamiliar' background has not resulted in any substantial modification of this enzyme.

The relative rates of the salicylate hydroxylase of the parent strain WR401 differ from those of the hybrid WR 4016. It appears that selection with chlorosalicylate drastically modified the substrate specificity of the enzyme originally functioning in methylsalicylate metabolism in favour of a more effective turnover of halogenated salicylates. Similar results were obtained by other workers during the construction of chloroaniline degraders (Latorre et al. 1984).

In this study we offer another example of the effectiveness of the in vivo evolution of a new pathway for xenobiotics by cocultivation of organisms harboring complementary catabolic activities. In order to produce a new functional hybrid pathway this experimentally rather primitive method requires culture conditions for enhanced genes transfer of genes plus adaptation i.e. the accumulation of random genetic changes.

An alternative strategy for the construction of strains with novel degradative properties has been carried out recently (Lehrbach et al. 1984). Thus, the transformation in vitro of cloned genes of a salicylate hydroxylase into Pseudomonas sp. B13 produced derivatives of this strain with the capability to degrade chlorosalicylates. The manipulation in vitro has one important advantage over conventional genetic crosses: it allows the experimenter to precisely select the genes which are essential for the hybrid pathway he intends to construct. By this means the introduction of superfluous genetic material coding for unproductive or counterproductive enzymes (i.e. C230 in the case of chlorocatechol catabolism) was avoided.

One very important limitation of this method is that in order to manipulate the desired DNA fragments into a hybrid catabolic pathway extensive knowledge of the biochemistry and the genetic organisation of existing complementary catabolic sequences is required. Therefore in practice the in vitro approach for the solution of specific problems of xenobiotic degradation is restricted to those cases that prove insoluble by natural genetic exchange and adaptation. In an accompaning paper we demonstrate the improvement of strain WR 4016 after prolonged subcultivation on chlorosalicylates.

Acknowledgements. We wish to thank the Federal Ministry for Research and Technology (Bundesministerium für Forschung und Technologie) for supporting this investigation. We wish to thank Prof. Dr. Walter Reineke for helpful discussions during this investigation.

\section{References}

Alexander M (1975) Environmental and microbiological problems arising from recalcitrant molecules. Microb Ecol 2:17-27

Bartels I, Knackmuss HJ, Reineke W (1984) Suicide inactivation of catechol 2,3-dioxygenase from Pseudomonas putida $\mathrm{mt}-2$ by 3-halocatechols. Appl Environ Microbiol 47:500-505

Bayly RC, Wigmore GJ, McKenzie DJ (1977) Regulation of the enzymes of the meta cleavage pathway of Pseudomonas putida, the regulon is composed of two operons. J Gen Microbiol 100:71-79

Bradford MM (1976) A rapid and sensitive method for the quantitation of microgram quantities of protein utilizing the principles of protein dye-binding. Anal Biochem 72:248 - 254 
Brilon C, Beckmann W, Knackmuss HJ (1981) Catabolism of naphthalenesulfonic acid by Pseudomonas sp. A3 and Pseudomonas sp. C22. Appl Environ Microbiol 42:44-45

Dorn E, Hellwig M, Reineke W, Knackmuss HJ (1974) Isolation and characterization of a 3-chlorobenzoate degrading pseudomonad. Arch Microbiol 99:61 - 70

Dorn E, Knackmuss HJ (1978a) Chemical structure and biodegradability of halogenated aromatic compounds: two catechol 1,2-dioxygenases from a 3-chlorobenzoate-grown pseudomonad. Biochem J 174:73-84

Dorn E, Knackmuss HJ (1978b) Chemical degradability of halogenated aromatic compounds. Substituent effects on 1,2-dioxygenation of catechol. Biochem J 174:85-94

Evans WC, Smith BSW, Fernley HN, Davies JI (1971 a) Bacterial metabolism of 2,4-dichlorophenoxyacetate. Biochem J 122: $543-551$

Evans WC, Smith BSW, Moos P, Fernley HN (1971 b) Bacterial metabolism of 4-chlorophenoxyacetate. Biochem J 122:509517

Hartmann J, Reineke W, Knackmuss HJ (1979) Metabolism of 3-chloro-, 4-chloro- and 3,5-dichlorobenzoate by a pseudomonad. Appl Environ Microbiol 37:421 -428

Horvath RS (1972) Microbial cometabolism and the degradation of organic compounds in nature. Bacteriol Rev 36:146-155

Jeenes DJ, Reineke W, Knackmuss HJ, Williams PA (1982) TOL plasmid pWWO in constructed halobenzoate-degrading Pseudomonas strains: enzyme regulation and DNA structure. J Bacteriol 150:180-187

Katagiri M, Maeno H, Yamamoto S, Hayaishi O, Kitao T, Oae S (1965) Salicylate hydroxylase, a monooxygenase requiring flavin adenine dinucleotide. II. The mechanism of salicylate hydroxylation to catechol. J Biol Chem 240:3414-3417

Knackmuss HJ, Hellwig M, Lackner H, Otting W (1976) Cometabolism of 3-methylbenzoate and methylcatechols by a 3-chlorobenzoate utilizing Pseudomonas: accumulation of (+) 2,3-dihydro-4-methyl- and (+) 2,5-dihydro-2-methyl-5oxo-furan-2-acetic acid. Europ J Appl Microbiol 2:267-276

Latorre J, Reineke W, Knackmuss HJ (1984) Microbial metabolism of chloroanilines: enhanced evolution by natural genetic exchange. Arch Microbiol 140:159-165

Lehrbach PR, Zeyer J, Reineke W, Knackmuss HJ, Timmis KN (1984) Enzyme recruitment in vitro: use of cloned genes to extend the range of haloaromatics degraded by Pseudomonas sp. strain B13. J Bacteriol 158:1025-1032

Leisinger T, Hütter R, Cook AM, Nüesch J (1981) Microbial degradation of xenobiotics and recalcitrant compounds. FEMS Symposium No 12. Academic Press, New York

Morris CM, Barnsley EA (1982) The cometabolism of 1-, and 2-chloronaphthalene by pseudomonads. Can J Microbiol 28: $73-79$

Murray K, Duggleby CJ, Sala-Trepat JM, Williams PA (1972) The metabolism of benzoate and methylbenzoate via the metacleavage pathway by Pseudomonas arvilla $\mathrm{mt}-2$. Eur J Biochem $28: 301-310$

Nakazawa T, Yokota T (1977) Isolation of a mutant TOL plasmid with increased activity and transmissibility from Pseudomonas putida (arvilla) mt-2. J Bacteriol 129:39-46
Nozaki M (1970) Metapyrocatechase (Pseudomonas). In: Tabor H, Tabor CW (eds) Methods in enzymology, vol 17A. Academic Press, New York, pp 522-525

Reineke W, Knackmuss HJ (1979) Construction of haloaromatics utilizing bacteria. Nature 277:385-386

Reineke W, Knackmuss HJ (1980) Hybrid pathway for chlorobenzoate metabolism in Pseudomonas sp. B13 derivatives. J Bacteriol 142: $467-473$

Reineke W, Jeenes DJ, Williams PA, Knackmuss HJ (1982a) TOL plasmid pWWO in constructed halobenzoate-degrading Pseudomonas strains: prevention of meta pathway. J Bacteriol 150:195-201

Reineke W, Wessels SW, Rubio MA, Latorre J, Schwien U, Schmidt E, Schlömann M, Knackmuss HJ (1982b) Degradation of monochlorinated aromatics following transfer of genes encoding chlorocatechol catabolism. FEMS Microbiol Lett 14:291 - 294

Sala-Trepat JM, Murray K, Williams PA (1972) The metabolic divergence in the meta cleavage of catechols by Pseudomonas putida NCIB 10015. Physiological significance and evolutionary implications. Eur J Biochem 28:347-356

Schmidt E, Knackmuss HJ (1980) Chemical structure and biodegradability of halogenated aromatic compounds. Conversion of chlorinated muconic acids into maleoylacetic acid. Biochem J 192:339-347

Schmidt E, Remberg G, Knackmuss HJ (1980) Chemical structure and biodegradability of halogenated aromatic compounds. Halogenated muconic acids as intermediates. Biochem J 192: $331-337$

Schmidt K, Liaaen-Jensen S, Schlegel HG (1963) Die Carotinoide der Thiorhodoceae. 1. Okenon als Hauptcarotinoid von Chromatium okenii Perty. Arch Mikrobiol 46:117-126

Schreiber A, Hellwig M, Dorn E, Reineke W, Knackmuss HJ (1980) Critical reactions in fluorobenzoic acid degradation by Pseudomonas sp. B13. Appl Microbiol 39:58-67

Schwien U, Schmidt E (1982) Improved degradation of monochlorophenols by a constructed strain. Appl Environ Microbiol $44: 33-39$

Stanier RY, Palleroni NJ, Doudoroff M (1966) The aerobic pseudomonads: a taxonomic study. J Gen Microbiol 43:159-271

White-Stevens R, Kamin H (1972) Studies of a flavoprotein, salicylate hydroxylase, requiring flaving adenine dinucleotide. I. Preparation, properties and the uncoupling of oxygen reduction from hydroxylation. J Biol Chem 247:2358-2370

Wigmore GJ, Bayly RC (1974) A mutant of Pseudomonas putida with altered regulation of the enzymes for the degradation of phenol and cresols. Biochem Biophys Res Commun 60:48-55

Williams PA, Murray K (1974) Metabolism of benzoate and the methylbenzoates by Pseudomonas putida (arvilla) $\mathrm{mt}-2$ : evidence for the existence of a TOL plasmid. J Bacteriol 120:416-423

Received October 25, 1985/Accepted March 25, 1986 